\title{
sciendo
}

\section{Rethinking the state-market relations in the New Age of development}

\author{
Paul DOBRESCU \\ National University for Political Studies and Public Administration, Bucharest, Romania \\ paul.dobrescu@comunicare.ro \\ Flavia DURACH \\ National University for Political Studies and Public Administration, Bucharest, Romania \\ flavia.durach@comunicare.ro
}

\begin{abstract}
This paper discusses, from a conceptual and theoretical perspective, the recent debates on the relation between the state and the market as drivers of national development. Since the end of the Cold War, three periods are distinguishable according to the way in which development is discussed, envisaged, and designed through state policies. The first one starts from the end of the Cold War and leads to the 2008-2009 crisis, the second includes the ten years of recovery, while the last is unfolding at the moment. The argument takes globalization into account as the background for development, during the three decades observed. The paper analyses the way in which the state-market relationship was envisaged during each period, both in the developed and emerging economies. The paper identifies the factors that ensure steady development, with an emphasis on current challenges. Lastly, the paper presents the particular experience of Central and Eastern Europe during its transition from the communist regime to democracy. The conclusion is that the better understanding of the relationship between globalization and development, the faster their evolution for a given country.
\end{abstract}

Keywords: globalization, development, national progress, state-market relations.

Please cite the article as follows: Dobrescu, P. and Durach, F. (2018), "Rethinking the state-market relations in the New Age of development", Management \& Marketing. Challenges for the Knowledge Society, Vol. 13, No. 4, pp. 1276-1288. DOI: 10.2478/mmcks-2018-0036.

\section{Introduction}

Ten years after the economic crisis that swiped the worlds' economies, the globe is experiencing another long-lasting turmoil. Recovery in the post-crisis period has been difficult. It left deep wounds for many countries: large debts, rising inequalities, both at national and supranational levels, and social unrest. Many voices warn of another recession to come (The Economist, 2018d). When the IMF Director herself urges nations to „Fix the roof while the sun is still shining” (Lagarde, 2018), and to dedicate their efforts to creating a fiscal buffer for hardships to come, then the world needs to listen. In fact, the numerous analyses published by renowned experts and highly reputed institutions worldwide confirm the new "esprit du temps", namely the exhaustion of harmonious international cooperation. A climate of insecurity is slowly taking its place as the global economy is affected by multiple-party trade wars.

There are many factors to be held responsible for this evolution; among them is the way in which economic development was envisaged and promoted during the last decades. Studying the perspectives on development in the 30 years that passed after the end of the Cold War allows us to distinguish between three distinct stages, or periods. The first one starts from the end of the Cold War and leads to the 2008-2009 crisis, the second includes 
the ten years of recovery, while the last - understudied and misunderstood - is unfolding now. Before making a brief analysis of the three stages, we must add that during these three decades development took place with globalization as the background process. Also, there is a significant development of the knowledge economy, which changes many rules of the economic game (Bratianu, 2017, 2018; Bratianu \& Bejinaru, 2017; Dima et al., 2018; Hadad, 2018).

Consequently, any discussion on development must consider this new landscape. To the perceptive eye, the following correlation becomes apparent: the better societies deciphered the relationship between globalization and development, the faster their evolution.

\section{The first period: blind faith in globalization}

The first period unfolded under the influence of two significant processes. One of them was the prominence of the idealistic view on the relation between development and globalization. We owe to Dani Rodrik the harshest critique of this view, encapsulated in the Washington Consensus. In his work from 2011, the American professor questioned the belief that globalization will automatically lead to the eradication of poverty in underdeveloped nations: „The Washington Consensus derived its appeal from a simple narrative about the power of globalization to lift developing nations out of poverty. But rather than promote the mixed, pragmatic strategies that China and others had employed in order to develop domestic industrial capabilities, advocates of this narrative stressed the role of openness to the global economy... Let these countries (n.n. poor countries) open themselves up to international trade and investment and a rising tide of trade will pull them up from poverty" (Rodrik, 2011, pp. 164-165).

This optimistic view seduced experts, and became the mantra of its times. Alternative views were ignored or looked down upon. Rodrik remembered the suspicion with which his own attempts to challenge the inconsistencies of the Washington Consensus had been met: „The idea of free trade as an engine of growth had become such a sacred cow that someone who revisited the evidence needed to have his motives questioned" (Rodrik, 2011, p. 167).

In the end, the viability of The Washington Consensus' main axioms started to crumble under the impact of what we may call its disappointing record. In 2003, even John Williamson, who coined the term Washington Consensus for the first time, acknowledged that it had become a "damaged brand" and concluded that "When a term has come to acquire such different meanings, it is time to drop it from the vocabulary" (Williamson, 2003, p. 12). The following year, Anne Krueger authored an article suggestively entitled „Meant Well, Tried Little, Failed Much”, incriminating „rhetoric seen as alternative to real reform, or at least as a way of buying time" (Krueger, 2004). The stance of Krueger, the Acting Managing Director of the IMF, suggests the realization that development must be guided by structural reforms had become wide-spread in the institution. "Too many countries around the world are performing below potential. The ability to deliver faster growth, raise living standards and reduce poverty depends on sound economic policies. In too many places, such policies are still proving elusive. In too many places, sound, sustainable policies are seen as an alternative to growth and poverty reduction. Yet experience has shown over and over again that the opposite is true: sound policies offer the best hope of rapid growth" (Krueger, 2004). 
Not to mention that even Jeffrey Sachs and Andrew Warner, two main contributors to the driving ideas of the Washington Consensus, reconsidered their beliefs later on. They initially expressed support for the direct influence of liberalization of the international trade on economic growth, by stating that "Open economies tend to converge, but closed economies do not. The lack of convergence in recent decades results from the fact that the poorer countries have been closed to the world. This is now changing with the spread of trade liberalization programs, so that presumably the tendency toward convergence will be markedly strengthened" (Sachs \& Warner, 1995, p. 3). Later on, they nuanced their argument by emphasizing the need for domestic reform. During a conference in Bucharest, Jeffrey Sachs openly admitted that he was naïf in the 1990s to believe in the absolute power of markets to fix everything. The US, he added, might be experiencing economic growth, but not universal well-being (Sachs, 2018, as cited by Pâslaru, 2018).

The aforementioned perspective that globalization automatically fosters development led to a passive, laissez-faire attitude. It seemed that no great efforts were needed, while the liberalization of international trade and globalization would lead to cumulative results within national communities. Nevertheless, this belief contradicted the history of human development. In any given era, for a society to develop, there is need for systematic, orderly efforts (which implies the need for state intervention) and vision (which means the leadership of the state and the intellectual elites). The perspectives on development that followed the end of the Cold War are superficial in their blind faith in development as a consequence of globalization, and in refusing to debate the matter further. Given this context, there is no surprise that the issue was ignored in the public spheres, being replaced by other concerns of the moment, such as modernization, dependency, Marxism, critical theory, multiculturalism.

The fragile balance between markets and governance, between globalization and the state, was broken. The state was pushed in the background, and its role, drastically limited. It was weakened and reduced to a passive receiver of commercial, technological and financial fluxes. The fundamental error was failing to realize that the markets and globalization require an active and intelligent state, one capable to take advantage of the new context, to meet the vitality of the markets. The fifteen years that preceded the Great Recession are defined by two fundamental errors, each with its own consequences at the strategic level. Firstly, the cooperation between the state and the market was insufficiently fostered. Instead of encouraging the collaboration of the two sides in reaching economic growth and development in a mutually beneficial fashion, they were placed in opposition. The state was forced into a position of weakness compared to the markets, leading to structural unbalances at the core of the developed economies. The markets and the global fluxes roared, while the state was limited in its capacity to respond, control, and project. The 2008-2009 crisis (caused, in part, by the aforementioned unbalance) caught the developed world unprepared.

The other error of judgement is blatantly ignoring the distinctive national contexts in which development is unfolding. There is a tension between the universal axioms of development and each state's unique potential. Neither of the two elements of the relationship can be emphasized in the detriment of the other without affecting the general balance. In the pre-crisis period, the excessive importance given to development's universal characteristics led to the implementation of standard recipes, as the expression of a kind of fundamentalism on the matter. In this vein, a World Bank's report from 2005 noted that "There is no unique universal set of rules. Sustained growth depends on key functions that 
need to be fulfilled overtime: accumulation of physical and human capital, efficiency in the allocation of resources, adoption of technology, and the sharing of the benefits of growth... Thus we need to get away from formulae and the search for elusive <<best practices>> and rely on deeper economic analysis to identify the binding constraints on growth. The choice of specific policy and institutional reforms should flow from these growth diagnostics. This much more targeted approach requires recognizing country specificities, and calls for more economic, institutional, and social analysis and rigor rather than a formulaic approach to policy making" (World Bank, 2005, p. XII).

The second process which imprinted its features during this stage is the rise of the emerging economies, namely East-Asian states, and China in particular. In Jonathan Fenby's words, "China is the main beneficiary of globalization" (Fenby, 2017, p. 1). His view is confirmed by two other renowned experts in international relations. Edward Luce noted that „In 1978, China had less 1 percent of global trade, and in 2013 it become the world's leading trading nation with almost a quarter of its annual flows. As recently as the turn of the twenty-first century, the US accounted for almost three times as much global trade as China... Nothing on this scale or speed has been witnessed before in history" (Luce, 2017, p. 21). In the same vein, Vincent Cable added that "China is not just the biggest economy in the world (with a GDP of $\$ 19.5$ trillion against $\$ 17.9$ trillion for the USA) but a middle income country with a per capita income of around $\$ 12,000$. This compares to $\$ 53,000$ in the US today and $\$ 2,500$ in China after the upheaval, material damage, and stagnation brought on by the Great Leap Forward followed by the Cultural Revolution" (Cable, 2017, p. 5). The author feels entitled to argue that, "In some ways, China's economic achievements have already exceeded his own ambitious expectations." (Cable, 2017, p. 4). What is the secret beyond the historic success of the world's largest country? The key is its obstinacy to focus on development, "the only hard truth" (Gao, 2018). The fluxes of globalization are, undoubtedly, essential. Ideas are the ones that synchronize investments, capital, and technology, and are the root of all progress. China is the supporter of the idea that development is the only truth that matters. In this formula we find the origins of China's governing programme which places development at the forefront of every national aspirations, and subordinating all other goals to it.

Furthermore, we must highlight its determination to preserve an openness to international fluxes of globalization, and to take full advantage of them. For any state that strives to accelerate its progress, globalization weighs as much as inexorable natural data. One cannot change this context; one can take advantage of it instead. From the open doors policy, initiated by Deng Siaopin in the dawn of China's reform, to Xi Jinping's policy, there is impressive continuity, adaptation to, and exploitation of the global economic trends (Chan, 2016). Today, China is not only the main beneficiary of globalization, as Fenby said, but also the nation best equipped to face its challenges.

The open doors policy was matched by an internal response, a strategy to balance the markets and the state, to offer the latter the right leverage to respond to the fluxes of globalization, and to anticipate international trends with a unitary, long term vision (the socalled longtermism). The balance may have not always been correctly deciphered, as many studies draw attention to China's authoritarian tendencies, or the prevalence of the state over the markets. Nevertheless, we must applaud the efforts to understand and balance these two fundamental factors for development. At the heart of the reform is "the need to proceed by experimentation", "the need to set and pursue long term goals" (Cable, 2017, p. 4 ), to maintain a balance between the economic and social implications of the development 
race, and to intervene and make corrections. Looking at China's outstanding evolution, it becomes difficult to choose one of the many mistakes the developed world made after the end of the cold war; was it the wrongful interpretation of the role of the state versus the role of the markets? Was it looking at the emerging economies with superiority and contempt, despite their irrefutable results? Development means staying alert to a nation's own progress, as well as the progress of others.

\section{The second period: hard lessons from the economic crisis}

The second stage encompasses the crisis and post-crisis periods. Few lessons were drawn from the experience of the recession. We can even talk about an economic legacy of the crisis, especially the massive indebtedness which is slowing down recovery. In the aftermath of the crisis, many sufferings originating in the previous periods have become highly symptomatic, showing just how unhealthy the developed economies were.

Christine Lagarde, managing director of IMF, offered the best depiction of this period. Referring to "the dynamic role of emerging countries”, Lagarde (2015a) commented that „These countries helped pull the global economy back from the brink of another Great Depression a few years ago. They have accounted for almost 80 percent of global growth over the past five years. They now generate more than half of global output". How did the emerging countries managed to pull the developed states and the global economy from the brink of disaster? The answers can be found in their impressively rapid economic growth and development in the pre-crisis period. Their rhythms of evolution indicate the health of the system. "The early 2000s started as a wild decade with unparalleled growth rate, which changed the world in a matter of years. In 2007, for instances, China's growth rate was 14.2\%, India's 10.1\%, Russia's 8.5\% and Brazil's 6.1\%. At the beginning of the decade, the emerging countries' GDP share in the world output was 38\%" (Dobrescu, 2017, p. 4). How did the emerging economies manage to reach these exceptional results? Undoubtedly, by identifying the aforementioned balance between the contribution of the state and the freedom of the markets.

Another piece of the puzzle is the speed of economic recovery, which is rather disappointing. Lagarde emphasized, that "The world is stuck in a "new mediocre" growth pattern despite the $\$ 7$ trillion ( $\$ 9.6$ trillion) in quantitative easing measures from banks in industrial nations since the global financial crisis" (Lagarde, 2015b). She added: "My key message to global policymakers: they need to upgrade their policy recipes to reinvigorate growth and reduce global uncertainty" (Lagarde, 2015b). Her statement must be understood in the light of the acute lack of order in financial and banking systems of the developed world, and the costly societal imbalances.

To illustrate this point, Niall Ferguson argued that: „Plausible estimates for the losses that the financial crisis inflicted on the United States alone range from $\$ 5.7$ trillion to $\$ 13$ trillion, whereas the largest estimate for the cost of the war on terrorism stands at \$4 trillion” (Ferguson, 2017, p. 75). Meanwhile, the national debt skyrocketed: „It stood at approximately $\$ 4$ trillion when the Cold War ended, has risen to $\$ 20$ trillion today, and is projected to exceed $\$ 25$ trillion by the end of this decade. The United States has become a country that does not finish what it starts and then borrows exorbitantly to conceal its failures" (Bacevich, 2017, p. 65).

Lastly, we would like to highlight the impact of inequality. In recent years, many reputed authors, such as Thomas Piketty and Branko Milanovici, or high-ranking public figures and political leaders, such as Barack Obama and Pope Francisc, expressed their 
concerns over this phenomenon. The IMF director Christine Largarde warned us of rising inequality, a situation rooted in the pre-crisis period, and exacerbated by the negative forces of the recession. Her warning, coming from an international financial organization, is particularly significant, suggesting that the current levels of inequality threaten not only social cohesion, but economic growth as well. "Why is this relevant right now? Because the theme of growing and excessive inequality is not only back in the headlines, it has also become a problem for economic growth and development" (Lagarde, 2015c).

After the crisis, many nations focused on economic recovery and growth, an understandable reaction in the aftermath of recession. However, there is growing evidence in recent years that both economic and social issues must be taken into account for development to take place; and that irreconcilable social gaps and rising inequality must be contained and reduced. The year 2016 acted as a milestone in this regard, due to some unsettling political evolutions (i.e. Brexit and the victory of Donald Trump). Lagarde's message a year earlier was premonitory: "My key message tonight is this: reducing excessive inequality - by lifting the 'small boats' - is not just morally and politically correct, but it is good economics. You do not have to be an altruist to support policies that lift the incomes of the poor and the middle class. Everybody will benefit from these policies, because they are essential to generate higher, more inclusive, and more sustainable growth... In other words, if you want to see more durable growth, you need to generate more equitable growth" (Lagarde, 2015c).

\section{The third period: rethinking prior beliefs under the pressure of the digital revolution}

The third stage, which is unfolding now, provides a picture in reverse, one in which the role of the state is favoured in the detriment of globalization and the markets. When Jan Bremmer (2012) published his work, Every nation for itself, this perspective seemed remote. Four short years later, it found its materialization in America's new policy, "America first".

The new zeitgeist is contaminating not only politicians, but scholars as well. Many experts who used to support globalization, are now reconsidering their stance. It is the case of Lawrence Summers (2016), former US Treasury secretary: "A new approach has to start from the idea that the basic responsibility of government is to maximize the welfare of citizens, not to pursue some abstract concept of the global good. People also want to feel that they are shaping the societies in which they live". In conclusion, a new approach is gaining ground fast: "Reflex internationalism needs to give way to responsible nationalism or else we will only see more distressing referendums and populist demagogues contending for high office”. On a similar note, Xavier Solana (2017) draws attention on the significance of internationally shared issues, neglected in times of nationalism and protectionism: „If all countries put their own interests first, paying no heed to others, competition will quickly overwhelm common interests. If nobody is ever willing to yield, we will all lose".

While before the crisis the developed world prospered effortlessly, and while the post-crisis recovery was a confusing process, today we are re-entering a genuine development race, with high stakes for any country. This period emphasises clear development goals, stemming from the digital revolution and the possibilities it entails. After years of discussing the Kondratiev waves, and waiting for the dawn of a new technical 
revolution, the digital innovations finally emerged, together with the question: are we ready for them?

Many expect the new revolution to produce tectonic shifts in many fields apart from the technological one (e.g. management, prognosis, publicity). Albeit very complex, the digital revolution has artificial intelligence (AI) as its flagship. AI is expected to change economic activities for good. Thinking about the impact of the new tech changes, Vladimir Putin mentioned: "Artificial intelligence is the future... Whoever becomes the leader in this sphere will become the ruler of the world." (Putin, 2017, apud Vincent, 2017).

In the given context, development will be shaped by each country's capacity to use artificial intelligence to its advantage. Not surprisingly, the competition unfolds at the top of the world order, by engaging the most prominent players of the developed world (US in particular) and the leaders of the emerging world (especially China, whose GDP is roughly $50 \%$ of the total GDP or BRICS). The Economist has dedicated many pages to the topic, through special issues such as: "Artificial Intelligence" (2016a), "The Battle for Digital Supremacy" (2018a), "AI-spy" (2018b). What these reports have in common is the concern that China's progress threatens American dominance: "It is one thing for a country to dominate television and toys, another the core information technologies. They are the basis for the manufacture, networking and destructive power of advanced weapons systems. More generally, they are often subject to extreme networks effects, in which one winner establishes an unassailable position in each market. This means that a country may be squeezed out of vital technologies by foreign rivals pumped up by state support...America is right to worry about Chinese tech. But for America to turn its back on the things that made it great is no answer" (The Economist, 2018c, p. 11).

It is expected that the digital revolution will change the economic hierarchy of the world, by having top-down effects. It is plausible to see, it the near future, the widening and deepening of development gaps between the leaders of the digital revolution, and its followers. In other words, the tech revolution could be the start of a new age of divergence, as it already happened during the first technological revolution, which propelled Europe to being the leader of the world. Jan Bremmer writes about "The Strongman Era": "In every region of the world, changing times have boosted public demand for more muscular, assertive leadership. This tough-talking populists promise to protect 'us' from 'them'. Depending on who's talking, 'them' can mean the corrupt elite or the grasping poor; foreigner or members of racial, ethnic or religious minorities. Or disloyal politicians, bureaucrats, bankers or judges. Or lying reporters. Out of this divide, a new archetype of leader has emerged. We're now in the strongman era" (Bremmer, 2018). While we do not contradict Bremmer, we would like to amend his point of view. The analysis of the populist rhetoric must be nuanced by taking development into account. In the statements of the "strongmen"-type of leaders in Russia, China, Turkey, Hungary, mentioned by the author, development and national progress play a key role, and the evolutions of the respective countries support their policies.

For all nations of the world to past the test of the digital revolution, they must act quickly, and prepare thoroughly. Winners and losers will be determined by the presence or absence of long-term investments in research, the concern for sustainable and inclusive development, and by the public attachment to the development goals. From this point of view, the most striking description can be found in the last pages of Ian Goldin's recent work: "Development is not simply or mainly about the lives of others. It is about ourselves and what we care about. Development is about who we are and our collective future" 
(Goldin, 2016, p. 171). The life of a nation can be analysed from many perspectives. The way in which it has managed to foster its own development is fundamental. Nothing else is more comprehensive and significant. Development accounts for what a nation is, and intends to become. That is why development is the genuine and enduring brand of a country.

Irrespective of future evolutions, the relation between globalism and localism, and between the state and the markets must be redesigned, leading to a new era in the economic and social life. Today, every major country intends to decide what model of development is best fitting. It is not just a competition of models, but also a competition of vanities. If we are to judge things calmly, the power of a model lies not only in its intrinsic value, but also in its capacity to adapt to some particular conditions. Therefore, the generalization of a model of development is a very risky endeavour, because it can have undesired results. Emphasizing diversity is extremely important. However, this does not mean underestimating common traits and certain universal requirements. Striking a balance between universal requirements and local potential is and should be the main tenet of effort focused on development. The right combination is the winning factor in the development equation. The "potent combination", in the terms of Alan Greenspan (2007, p. 13).

\section{Methodology}

This paper provides conceptual clarifications on the main orientations in envisaging development, and the state-market relationship dynamics. By using the insights on the three stages of reconfiguring development after the end of the Cold War, we analyse the specific experiences of Central and Eastern Europe (CEE), with a particular focus on those states that are currently EU members. Our analysis is based on the Goldin's theory of development, economic growth and social change (Goldin, 2016), and on the Dobrescu's perspective on the dynamics of globalization (Dobrescu, 2017). We turn to expert opinion and data provided by prestigious intuitions, such as the World Bank, to better understand:

1. How have the three stages of conceptualizing development been felt in CEE?

2. What are the most significant development-related issues in CEE?

Our paper is aligned with the main directions of the qualitative research and in concordance with the requirements of a coherent conceptual analysis of economic and social phenomena.

\section{Analysis and discussion. Central and Eastern Europe: pain without gain}

The three periods described above, summarizing thirty years of thinking and relating to the concept of economic development, have been felt intensely in Europe, and especially in its Central and Eastern European (CEE) region. The shift from the communist regime to democracy made development a very sensitive issue for the states in the region. Building a functional market economy posed tough challenges related to the implementation of new mechanisms. A great effort of adaptation was required from political leaders and the population. During the first stages, the region embraced globalization, global markets, and the international economic fluxes as an alternative to its isolation behind the Iron Curtain. CEE states felt compelled to embrace the openness that globalization entailed. They also felt the need to let the market forces express themselves, since markets had painfully stalled under the previous regime. As vital as opening up was, it unwillingly led to excess in betting success on globalization alone. Restructuring the economy went too far in countries such as 
Romania and Bulgaria, where the industry practically collapsed. Investments dropped, while the traditional commercial partners followed the same faith; CEE witnessed a stark decline in GDP. "For most countries emerging from the former Soviet Union, the 1990s will be remembered as a costly and traumatic decade. Sharp declines were followed by a prolonged and as yet incomplete recovery, with results varying from relative success in the Czech Republic, Hungary, and Poland to costly transitions in most other countries" (World Bank, 2005, p. XII).

Against this background, the economic crisis reached the vulnerable eastern economies, leading to severe economic and social consequences. Public discontent built up under the pressure of the austerity measures - pushing the public to the brink of radicalization, in some cases. We believe two are the most significant issues for the CEE region. Firstly, the aforementioned relationship between the state and the market. Often, this crucial matter is examined in an abstract fashion, without acknowledging the state's straightforward or indirect responsibilities for fostering development. Furthermore, there is a lack of realization that the state cannot be fully replaced by any other actor or agent.

The state is particularly responsible for ensuring the human and material infrastructure of development: „Economic development requires basic physical and human infrastructure: transportation, energy, education, science. Private sector capitalists rarely provide roads, airports, mass transits, mass education or basic research because there is no way to make these activities economically profitable. If the economy is to have vital prerequisites for growth, those prerequisites must be provided by some institution motivated by something other than short term profit. The state - with its concern over longterm national prosperity - has been critical to the provision of physical and human infrastructure. Governments build roads, build airports, build schools and pay for science. This is a gigantic contribution to economic development" (Blumberg \& Cohn, 2016, pp. 6-7). We must add that all CEE states are actively involved in their effort to modernize their human and material infrastructure.

The second issue regards the evolution of social inequality, which in turn amplifies discontent and social instability. In this respect the way in which the national income is distributed and redistributed matters most. It is not only the size of the "pie" that counts, but also the way it is shared. In CEE, both aspects are under less than favourable circumstances. The "pie" is small and unevenly shared. The "World Inequality Report 2018", authored by renowned experts in inequality, underlines the most worrying trend: „Perhaps the most striking finding of this report is that, at the global level, the top $0.1 \%$ income group has captured as much of the world's growth since 1980 as the bottom half of the adult population. Conversely, income growth has been sluggish or even null for the population between the global bottom 50\% and top 1\%. This includes North American and European lower -and middle-income groups" (Alvaredo et al, 2018, p. 317).

The aforementioned tendencies vary in their materialization from country to country and from region to region. Undoubtedly, the processes we discussed will affect Central and Eastern Europe to the highest extent, due to the region's modest economic performances and its insufficiently calibrated policies of distribution and redistribution. The current stage of development finds Central and Eastern Europe within a lengthy process of self-discovery.

\section{Conclusions}


The present paper provides an overview of the successive approaches of development strategies since the end of the Cold War, leading to the conclusion that development gradually lost its place among the top priorities in many states. For instance, the United States' orientations on this issue were strikingly different at the end of the Cold War, compared to the end of World War II. Then, the famous Point Four of the Inaugural Address that President Truman made on the $20^{\text {th }}$ of January, 1949, inaugurated the development age of the postwar period (Rist, 2014). Referring to the time that passed since end of the Cold War, Gilbert Rist talked about "globalization as simulacrum of development" (Rist, 2014, p. 211). There were two very different approaches towards development; each of them led to different results.

The 1990s were marked by a sense of triumphalism, leading the developed and the emerging countries to distance themselves from the critical, pragmatic evaluations of their own perspectives for development. In the pre-crisis period, many experts and renowned institutions started to criticize this development-related apathy. Unfortunately, the warnings formulated by these actors failed to permeate the mainstream of politics. What worked as a trigger for forced change was the 2008-2009 economic and financial crisis.

Post-crisis recovery was a confusing and excruciating process. The results of these efforts were rather modest and disappointing, and the majority of the developed economies failed to return to their pre-crisis growth rates until recent years. Within this period, 2016 was a turning point. With the election Donald Trump, with his new platform, development returned to the forefront of national priorities. The Trump administration favors a domestic focus instead of an international one. This change, summed up by the slogan "America first", has unwelcomed consequences in what concerns global issues that require joined efforts, such as fighting climate change.

Another distinctive feature is the rise of the emerging economies, especially Asian ones. Numerous studies draw attention to the changes in the global hierarchies this phenomenon entails. We would like emphasize a different aspect: the growing importance of fast developing economies; their positive experience with growth and development will become the object of interest of many other nations.

Three are the major issues the developed world has to face now. The first is related to managing the growing levels of sovereign debt, one of the main consequences of the 2008-2009 crisis, and a potential omen of another crisis to come. The second regards growing social inequality, both within countries and between countries (i.e. global inequality). This phenomenon has become a core issue in the developed world, favoring significant social shifts, such as support for populist leaders (e.g. Donald Trump), or Brexit.

Lastly, re-launching development requires the sustained efforts of the political and intellectual elites, to ensure sustainable and inclusive development, to restore the balance between social and economic issues, and between the international and national dimensions of development. Let us not forget that the reputable American economist Lawrence Summers, who was one of the representatives of the 1990s "esprit du temps" regarding development issues, later lamented „the development of the stateless elites whose allegiance is to global economic success and their own prosperity rather than the interests of the nation where they are headquartered" (Summers, 2008).

One final note on the three priorities - limiting the growth of the sovereign debt, reducing inequalities, and channeling elite-driven efforts for sustainable and inclusive development - is that they are particularly challenging for Central and Eastern Europe. 


\section{References}

Alvaredo, F., Chancel, L., Piketty, T., Saez, E. and Zucman, G. (eds). (2018), World inequality report 2018, The Belknap Press of Harvard University Press, Cambridge.

Bacevich, A. J. (2017), "Saving 'America first'. What responsible nationalism looks like", Foreign Affairs, September/October 2017 Issue.

Blumberg, R. L. and Cohn, S. (eds). (2016), Development in crisis. Threats to human wellbeing in the Global South and Global North, Routledge, London.

Bratianu, C. (2017), "Sharing economy: knowledge strategies for crazy times", In Tsui, E. and Cheung, B. (eds.), Proceedings of the $14^{\text {th }}$ International Conference on Intellectual Capital, Knowledge Management \& Organizational Learning, The Hong Kong Polytechnic University, Hong Kong (pp.29-35), 7-8 December 2017, Academic Conferences and Publishing International, Reading.

Bratianu, C. (2018), "Intellectual capital research and practice: 7 myths and one golden rule", Management \& Marketing. Challenges for the Knowledge Society, Vol. 13, No. 2, pp. 859-879.

Bratianu, C. and Bejinaru, R. (2017), "Knowledge strategies for increasing IC of universities", In Lopez, I.T., and Serrasqueiro, R. (eds.), Proceedings of the 9th European Conference on Intellectual Capital, Institute Universitario de Lisboa (ISCTE), Portugal, 6-7 April 2017 (pp. 34-42), Academic Conferences and Publishing International, Reading.

Bremmer, J. (2018), “The 'Strongmen Era' is here. Here's what it means for you”, Time, May 3, 2018. Retrieved from: http://time.com/magazine/south-pacific/5264282/may3rd-2018-vol-191-no-18-u-s/

Bremmer, J. (2012), Every nation for itself. Winners and losers in a G-Zero world, Portofolio, Penguin, New York.

Cable, V. (2017), Deng: architect of the Chinese superpower. From Deng to Xi: Economic reform. The new Silk Road, and the return of the Middle Kingdom, SPECIALREPORT, SR023 May 2017, 1-8.

Chan, S. P. (2016), "China will not shut the door on globalisation, president Xi Jinping vows", The Telegraph 20 November 2016. Retrieved from: https://www.telegraph.co.uk/business/2016/11/20/china-will-not-shut-the-dooron-globalisation-president-xi-jinpi/.

Dima, A.M., Begu, L., Vasilescu, M. and Massen, M.A. (2018). "The relationship between the knowledge economy and global competitiveness in the European Union", Sustainability, Vol.10, No. 6, pp. 1706, 1-15.

Dobrescu, P. (2017), The Century of the Emerging World, Development with a Vengeance, Cambridge Scholars Publishing, Cambridge.

Fenby, J. (2017), Will China dominate the 21-st century? 2nd edition, Polity, New York.

Ferguson, N. (2017), "The false prophecy of hyperconnection", Foreign Affairs, September/October 2017 Issue.

Gao, V. Z. (2018), "Why is Deng Xiaoping's 1992 Southern Inspection Tour still relevant today?" China Global Television Network. Retrieved from https://news.cgtn.com/news/3451444e79677a6333566d54/share_p.html

Goldin, I. (2016), The pursuit of development, economic growth, social change, and ideas. Oxford University Press, Oxford.

Greenspan, A. (2007), The age of turbulence, adventures in a New World, Penguin Books, New York. 
Hadad, S. (2018), "The geographic distribution of Knowledge Economy (KE) within the European Union (UE)", Management \& Marketing. Challenges for the Knowledge Society, Vol. 13, No. 3, pp. 1089-1107.

Krueger, A. (2004), "Meant well, tried little, failed much: policy reforms in emerging market economies", Remarks by Anne O. Krueger, Acting Managing Director, IMF, New York, March 23, 2004. Retrieved from https://www.imf.org/en/News/Articles/2015/09/28/04/53/sp032304a

Lagarde, C. (2015a), "Brothers and sisters, there is much to do", IMF-World Bank Annual Meetings Plenary, October 9. Retrieved from: http://www.imf.org/en/News/Articles/2015/09/28/04/53/sp100915

Lagarde, C. (2015b), "IMF-World Bank Annual Meetings, IMF Survey: Lagarde calls for new recipe for stronger growth, October 8, 2015. Retrived from: https://www.imf.org/en/News/Articles/2015/09/28/04/53/sonew100815a

Lagarde, C. (2015c), "Lifting the small boats", Address at Grandes Conferences Catholiques. Retrieved http://www.imf.org/en/News/Articles/2015/09/28/04/53/sp061715

Lagarde, C. (2018), "3 priorities for the global economy. Fix the roof while the sun is still shining", Retrieved from: https://www weforum.org/agenda/2018/04/fix-the-roofnow-three-priorities-for-the-global-economy.

Luce, E. (2017), The retreat of western liberalism, Little Brown, London.

Paslaru, S. (2018), "Profesorul american de economie Jeffrey Sachs, la București”, Ziarul financiar, 9 Mar 2018. Retrieved from: http://www.zf.ro/banci-siasigurari/profesorul-american-economie-jeffrey-sachs-bucuresti-naiv-anii-90-credputerea-pietelor-rezolva-totul-statele-unite-situatia-avea-crestere-economicacrestere-bunastare-generala-populatiei-17055371.

Rist, G. (2014), The history of development from western origins to global faith, Fourth edition, Zen Books, New York.

Rodrik, D. (2011), The globalization paradox: why global markets, states, and democracy can't coexist, Oxford University Press, Oxford.

Solana, J. (2017), "European Union First", Social Europe. Retrieved from: https://www.socialeurope.eu/2017/02/european-union-first/.

Summers, L. (2016), "Voters deserve responsible nationalism not reflex globalism", Financial Times, July 10, 2016. Retrieved from: https://www.ft.com/content/15598db8-4456-11e6-9b66-0712b3873ae1.

Summers, L. (2008), "America needs to make a new case for trade”, Financial Times, April 27, 2008. Retrieved from: https://www.ft.com/content/0c185e3a-1478-11dd-a741$0000779 f d 2 a c$.

The Economist (2016), "Artificial intelligence, a special report”, June 25Th, 2016. Retrieved from: $\quad$ https://ukshop.economist.com/products/special-report-on-artificialintelligence\#

The Economist. (2018a), "The battle for digital supremacy”, March 17th-23rd 2018.

The Economist. (2018b), “AI-spy, Artificial Intelligence in the workplace”, March 31st-April $6^{\text {th }} 2018$.

The Economist . (2018c), "The battle for digital supremacy", March 17th 2018.

The Economist. (2018d), "The next recession. How bad will it be?", October 13th-19th, 2018. 
Vincent, J. (2017), "The Russian president warned that artificial intelligence offers 'colossal opportunities' as well as dangers", The Verge, Sept. 4, 2017. Retrieved from: https://www.theverge.com/2017/9/4/16251226/russia-ai-putin-rule-the-world

Williamson, J. (2003), "From reform agenda to damaged brand name. A short history of the Washington Consensus and suggestions for what to do next", Finance \& Development, September 2003, 10-13.

World Bank. (2005), "Economic growth in the 1990s learning from a decade of reform", Retrieved from: http://www1.worldbank.org/prem/lessons1990s/chaps/frontmatter.pdf. 